Prepared in cooperation with the Bureau of Reclamation

\title{
Summary of Survival Data from Juvenile Coho Salmon in the Klamath River, Northern California, 2009
}

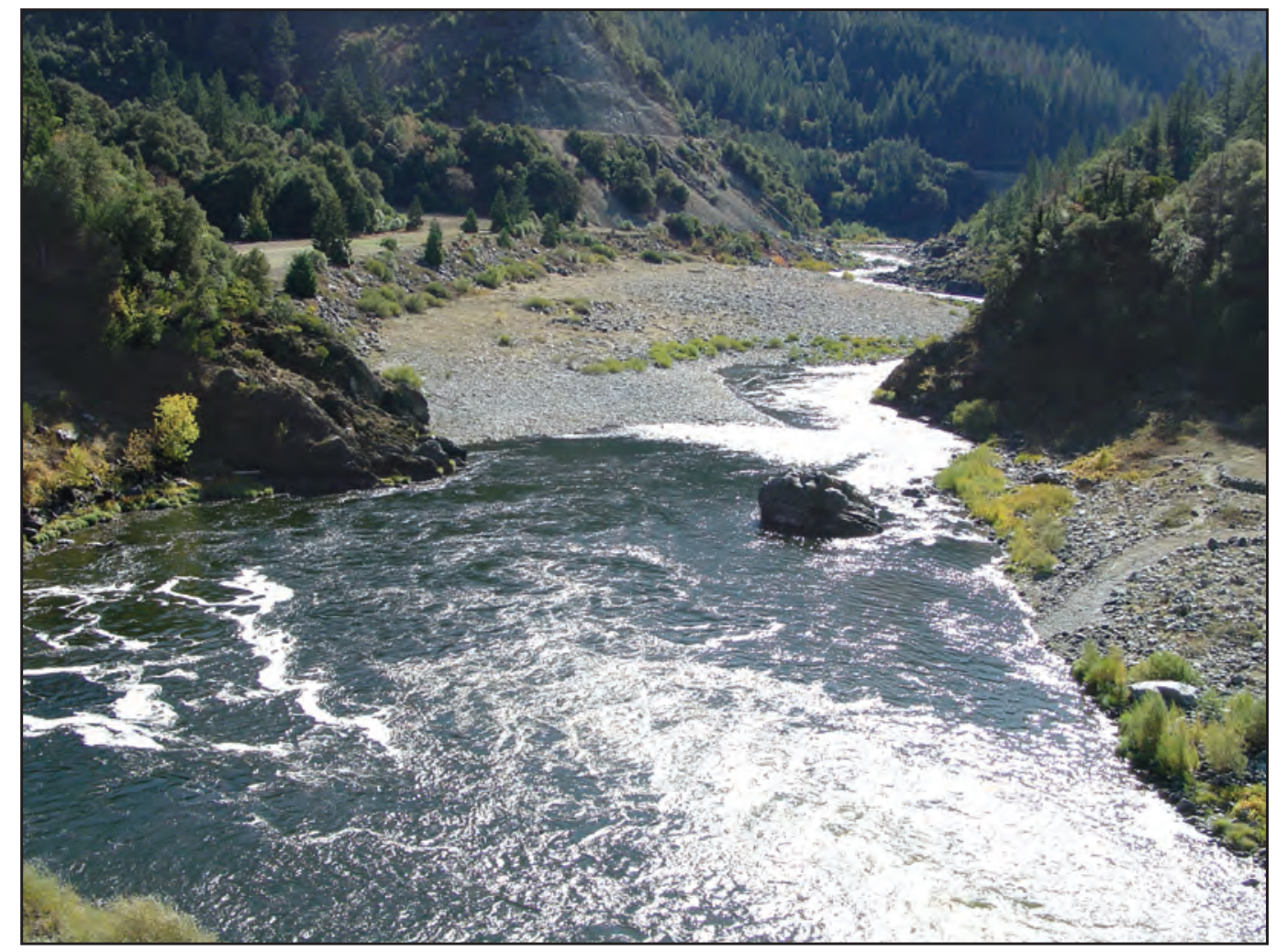

Open File Report 2009-1270 
Cover: Photograph of the Klamath River looking downstream near its confluence with the Salmon River, northern California. (Photograph taken by Steve Juhnke, U.S. Geological Survey, Cook, Washington, October 20, 2009). 


\section{Summary of Survival Data from Juvenile Coho Salmon in the Klamath River, Northern California, 2009}

By John W. Beeman and Steven D. Juhnke

Prepared in cooperation with the Bureau of Reclamation

Open File Report 2009-1270

U.S. Department of the Interior

U.S. Geological Survey 


\section{U.S. Department of the Interior \\ KEN SALAZAR, Secretary}

\section{U.S. Geological Survey \\ Marcia K. McNutt, Director}

U.S. Geological Survey, Reston, Virginia: 2009

For more information on the USGS—-the Federal source for science about the Earth, its natural and living resources, natural hazards, and the environment, visit http://www.usgs.gov or call 1-888-ASK-USGS.

For an overview of USGS information products, including maps, imagery, and publications, visit $h$ ttp://www.usgs.gov/pubprod

To order this and other USGS information products, visit http://store.usgs.gov

Suggested citation:

Beeman, J.W., and Juhnke, S.D., 2009, Summary of survival data from juvenile coho salmon in the Klamath River, northern California, 2009: U.S. Geological Survey Open-File Report 2009-1270, 8 p.

Any use of trade, product, or firm names is for descriptive purposes only and does not imply endorsement by the U.S. Government.

Although this report is in the public domain, permission must be secured from the individual copyright owners to reproduce any copyrighted material contained within this report. 


\section{Contents}

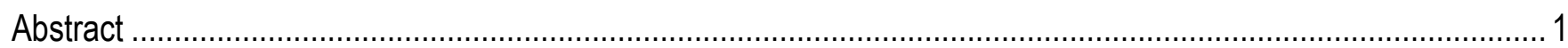

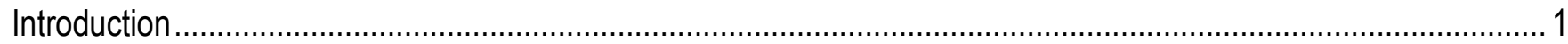

Survival of Juvenile Coho Salmon Through River Reaches........................................................................... 3

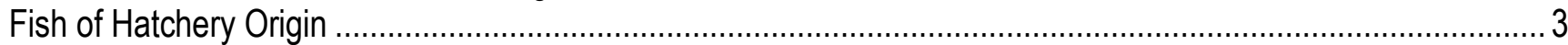

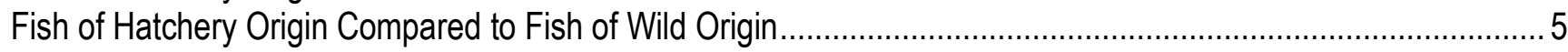

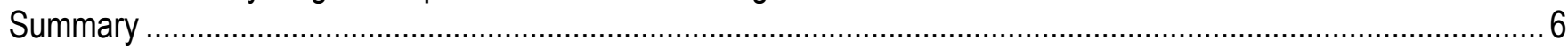

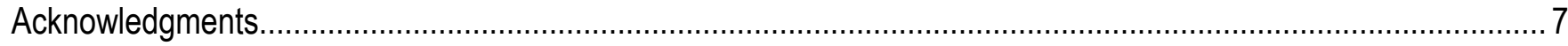

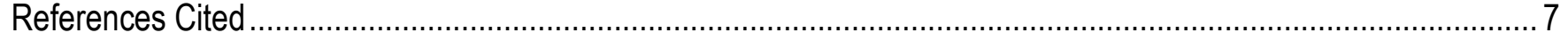

\section{Figure}

Figure 1. Map showing study area of the Klamath River juvenile coho salmon survival study, northern California, 2009

\section{Tables}

Table 1. Summary of models used to estimate apparent survival (Phi) and recapture probabilities $(\mathrm{P})$ of hatchery-origin juvenile coho salmon in study reaches of the Klamath River during spring 2009 4 Table 2. Estimated apparent survivals of radio-tagged juvenile hatchery-origin coho salmon in study reaches of the Klamath River during spring 2009. 4

Table 3. Summary of models used to estimate apparent survival (Phi) and recapture probabilities $(P)$ of hatchery- and wild-origin juvenile coho salmon in study reaches of the Klamath River during spring 2009 on dates at least four of each group were released

Table 4. Estimated apparent survivals of radio-tagged juvenile coho salmon of hatchery- and wild-origin in study reaches of the Klamath River during spring 2009. 
This page left intentionally blank 


\title{
Summary of Survival Data from Juvenile Coho Salmon in the Klamath River, Northern California, 2009
}

\author{
By John W. Beeman and Steven D. Juhnke
}

\begin{abstract}
A study of the effects of the discharge from Iron Gate Dam on the Klamath River on juvenile coho salmon during their seaward migration began in 2005. Estimates of fish survival through various reaches of the river downstream of the dam were completed in 2006, 2007, 2008, and 2009. This report describes the estimates of survival during 2009, and is a complement to similar reports for 2006, 2007, and 2008. For each year, a series of numerical models were evaluated to determine apparent survival and recapture probabilities of radio-tagged fish in several river reaches between Iron Gate Hatchery at river kilometer 309 and a site at river kilometer 33. The evaluations indicate that the primary differences among years are in the survivals through reaches upstream of the confluence of the Scott River with the Klamath River. Data from 2009, one of two years when fish from both hatchery and wild origins were available for analysis, indicate that survival of wild and hatchery fish are similar.
\end{abstract}

\section{Introduction}

In 2006, the U.S. Geological Survey (USGS) entered into a cooperative study with the Karuk Tribe of California, the Yurok Tribe, and the U.S. Fish and Wildlife Service to estimate the effects of the discharge of Iron Gate Dam on survival of juvenile coho salmon (Oncorhynchus kisutch) in the lower Klamath River, northern California. Funding for this study was provided by the Bureau of Reclamation, Klamath Basin Area Office. The purpose of the study was to provide information about the relation between survival of juvenile coho salmon and river water discharge in the Klamath River downstream of Iron Gate Dam [river kilometer (rkm) 310]. The study fish were part of the Southern Oregon/Northern California Coasts Evolutionary Significant Unit of coho salmon listed under the Endangered Species Act (ESA) in 1997. In 2006, both hatchery and wild fish were tagged, but in 2007 and 2008, the numbers of wild juvenile coho salmon in nearby tributaries were low and only hatchery fish were tagged. In 2009, we again tagged both hatchery and wild fish.

This report describes results from the 2009 study to date and is a complement to similar reports describing survival estimates in 2006, 2007, and 2008 (Beeman, 2007, 2008; Beeman and others, 2007, 2009). The design and methods of the studies were similar in each year, and are briefly described below. 
The study design was based on a need to estimate apparent survival probabilities of juvenile coho salmon in the Klamath River downstream of Iron Gate Dam. The analytical approach, described in Burnham and others (1987), is based on Cormack-Jolly-Seber capture-mark-recapture models (Cormack, 1964; Jolly, 1965; Seber, 1965). Apparent survival is the probability that an animal remains available for recapture. In the context of this study, it is the joint probability that the animal is both alive and migrates through the study area. As such, fish that stop migrating within the study area, travel to areas outside the mainstem Klamath River and do not return, or those that remain within the study area after the radio tags deplete their battery and cease transmitting, are counted as mortalities. All references to 'survival' in this document refer to apparent survival. Survival through all but the last of eight river reaches delineated (fig. 1) was estimated from data obtained by telemetry receiving equipment. Survival could not be estimated in the last reach because only the joint probability of survival and recapture is known in the last reach in Cormack-Jolly-Seber models.

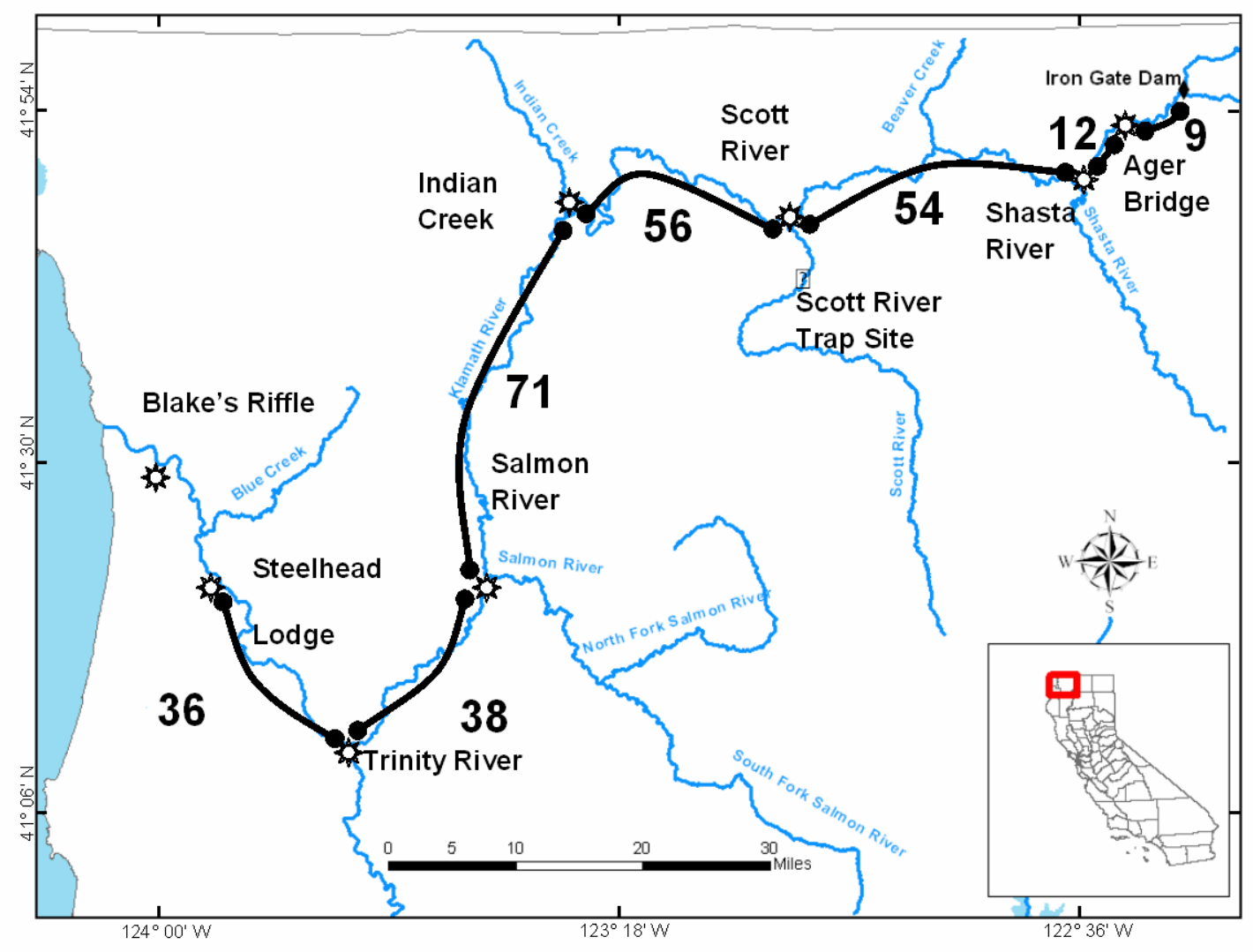

Figure 1. Map showing study area of the Klamath River juvenile coho salmon survival study, northern California, 2009. Detection sites are indicated by $\$$. Large, bold numbers indicate reach lengths in kilometers. Figure modified from U.S. Fish and Wildlife Service, Arcata, CA, 2006. 
In 2009, we surgically implanted radio tags into yearling coho salmon of hatchery origin from Iron Gate Hatchery, as well as into yearling coho salmon of wild (or natural) origin from the Scott River. The radio tags weighed 0.43 grams in air and had dimensions of $13.5 \mathrm{~mm}$ length, $5.3 \mathrm{~mm}$ width, and $3.3 \mathrm{~mm}$ height and had a $16 \mathrm{~cm}$ long trailing antenna. The hatchery fish ( $\mathrm{n}=189$ fish) were taken directly from a tank at the hatchery. The wild fish $(n=60$ fish) were taken from the catch of a rotary trap located at approximately rkm 8 of the Scott River, operated by the California Department of Fish and Game. In 2006, the wild fish were taken from a similar trap on the Shasta River. The intent of using both hatchery and wild groups was to determine if hatchery fish could be used as surrogates for the limited supply of wild fish to study factors affecting the survival of juvenile coho salmon. All fish were released into the Klamath River near the hatchery (rkm 309) at nautical twilight during several dates each week beginning on April 16, 2009, and ending on May 28, 2009. There were no mortalities of study fish during the holding, tagging, or releasing periods. No fish were released downstream as in some previous years due to differences in migratory behaviors and survivals of fish released near the hatchery and fish released near the Tree of Heaven campground (rkm 280) in 2007 (Beeman and others, 2008). Data were analyzed several months after the last fish was released; the last fish detection was on June 22, 2009. Twenty-five transmitters were held in a laboratory setting (submerged in water) to measure transmitter life. The tested radio transmitters lasted between 58 and 70 days, and the longest travel time recorded from a fish was $41.5 \mathrm{~d}$.

\section{Survival of Juvenile Coho Salmon Through River Reaches}

The survival of fish through each reach and over multiple reaches was estimated using the single-release design (Burnham and others, 1987). The modeling approach was similar to that used in previous years. A series of a-priori models was created and ordered in terms of parsimony using program MARK (White and Burnham, 1999). The analysis included a suite of models describing recapture probabilities and survival probabilities of fish from the two origins (hatchery and wild) in each of the common reaches. The models were ranked using a variant of Akaike's Information Criterion adjusted for small sample sizes (AICc) to determine which models were best supported by the data. Recapture probability and survival were then estimated from one or more of the models depending on the level of support each received. The general methods are described in Burnham and Anderson (2002). Because recapture probabilities were at or near 1.0, overdispersion - the presence of greater sampling variance than model-based variance-could not be estimated, but was believed to be negligible.

\section{Fish of Hatchery Origin}

Survival was estimated from the data collected on hatchery fish on all release dates (April 16 to May 28, 2009). The dataset included information for 189 fish after censoring from the analysis one animal that was found dead in a rotary screw trap between the Shasta and Scott Rivers. Three models were compared to evaluate various hypotheses of factors affecting recapture and survival probabilities. These models were based on differences in these probabilities among reaches as well as a common value of each parameter fitted to all reaches. The model based on differences in survival and recapture probabilities among reaches received nearly 95 percent of the model weight, indicating that it was clearly the most supported hypothesis of those evaluated (model 1, table 1 ). To incorporate model selection uncertainty, the estimates of recapture and survival probabilities were based on modelaveraged results of all models in the set listed in table 1 . In this procedure, the coefficients for each 
effect in each model are averaged across all models after weighting by the AICc weights (Burnham and Anderson, 2002). The model-averaged results indicated that recapture probabilities ranged from 0.77 [standard error (SE) 0.032] at the Ager Bridge site to 0.98 (SE 0.011) or greater at all other sites. The estimate of recapture probability at most sites was 1.0. The low estimate at the Ager Bridge site relative to that at the other sites was due to equipment failure over several days. The estimates of survival ranged from 0.870 (SE 0.031) through the 71-km reach from Indian Creek to the Salmon River, to 0.961 (SE 0.019) through the 9-km reach from Iron Gate Hatchery (the release point) to the Ager Road Bridge (table 2). The survival estimate through the $276 \mathrm{~km}$ reach from release at Iron Gate Hatchery to Steelhead Lodge was 0.555 (SE 0.038). Overall, the reach-specific estimates of survival from hatchery fish in 2009 were most similar to those from 2006, particularly upstream of the Scott River junction.

Table 1. Summary of models used to estimate apparent survival (Phi) and recapture probabilities $(\mathrm{P})$ of hatchery-origin juvenile coho salmon in study reaches of the Klamath River during spring 2009.

[Models are based on data from 189 hatchery fish from Iron Gate Hatchery. All fish were released in the Klamath River near the hatchery between April 16 and May 28, 2009. Rankings are based on AICc, a modification of the Akaike’s Information Criterion for small samples. A '.' indicates a single value fitted to all reaches]

\begin{tabular}{clrrrrrr}
\hline $\begin{array}{c}\text { Model } \\
\text { No. }\end{array}$ & \multicolumn{1}{c}{ Model } & AlCc & \multicolumn{1}{c}{$\begin{array}{c}\text { Delta } \\
\text { AlCc }\end{array}$} & $\begin{array}{c}\text { AlCc } \\
\text { weights }\end{array}$ & $\begin{array}{c}\text { Model } \\
\text { likelihood }\end{array}$ & $\begin{array}{r}\text { Number of } \\
\text { parameters }\end{array}$ & Deviance \\
\hline 1 & $\{$ Phi(reach), P(reach)\} & 840.839 & 0.000 & 0.948 & 1.000 & 15 & 8.586 \\
2 & $\{$ Phi(.), P(reach)\} & 846.644 & 5.806 & 0.052 & 0.055 & 9 & 26.662 \\
3 & $\{$ Phi(reach), P(.)\} & 958.441 & 117.602 & 0.000 & 0.000 & 9 & 138.458 \\
\hline
\end{tabular}

Table 2. Estimated apparent survivals of radio-tagged juvenile hatchery-origin coho salmon in study reaches of the Klamath River during spring 2009.

[Results are based on data from 189 fish released from Iron Gate Hatchery. All fish were released in the Klamath River near the hatchery between April 16 and May 28, 2009. Results are based on model-averaging the models in table 1. Estimates over multiple reaches were calculated as the product of the individual reach estimates with variances estimated using the delta method]

\begin{tabular}{|c|c|c|c|c|c|c|}
\hline \multirow{2}{*}{$\begin{array}{l}\text { Reach } \\
\text { No. }\end{array}$} & \multirow[b]{2}{*}{ Description } & \multirow{2}{*}{$\begin{array}{c}\text { Reach } \\
\text { length } \\
(\mathrm{km})\end{array}$} & \multirow{2}{*}{$\begin{array}{l}\text { Apparent } \\
\text { survival }\end{array}$} & \multirow{2}{*}{$\begin{array}{l}\text { Standard } \\
\text { error }\end{array}$} & \multicolumn{2}{|c|}{$\begin{array}{c}\text { 95-percent } \\
\text { confidence interva }\end{array}$} \\
\hline & & & & & Lower & Upper \\
\hline 1 & Release to Ager Road Bridge (rkm 300) & 9 & 0.961 & 0.019 & 0.902 & 0.985 \\
\hline 2 & Ager Road Bridge to Shasta River (rkm 288) & 12 & 0.930 & 0.021 & 0.875 & 0.962 \\
\hline 3 & Shasta River to Scott River (rkm 234) & 54 & 0.904 & 0.023 & 0.848 & 0.941 \\
\hline 4 & Scott River to Indian Creek (rkm 178) & 56 & 0.940 & 0.019 & 0.890 & 0.968 \\
\hline 5 & Indian Creek to Salmon River (rkm 107) & 71 & 0.870 & 0.031 & 0.797 & 0.920 \\
\hline 6 & Salmon River to Trinity River (rkm 69) & 38 & 0.912 & 0.025 & 0.849 & 0.950 \\
\hline \multirow[t]{4}{*}{7} & Trinity River to Steelhead Lodge (rkm 33) & 36 & 0.921 & 0.025 & 0.856 & 0.958 \\
\hline & Release to Shasta River & 21 & 0.894 & 0.027 & 0.841 & 0.947 \\
\hline & Release to Scott River & 75 & 0.808 & 0.032 & 0.746 & 0.871 \\
\hline & Release to Steelhead Lodge & 276 & 0.555 & 0.038 & 0.481 & 0.630 \\
\hline
\end{tabular}




\section{Fish of Hatchery Origin Compared to Fish of Wild Origin}

Numerical models developed with and without accounting for the effect of fish origin on recapture and survival probabilities were evaluated to determine if the data supported differences in survival based on fish origin. The comparisons were based on dates in which at least four fish from each origin were released (April 16 through April 30, 2009), providing 57 fish from each origin for analysis. A model of recapture probability based on differences between origins and among reaches received 71 percent of the AICc weight and was used in all models of survival. A model of recapture probability varying among reach, but not between origins, received 21 percent of the model weight. The use of either model produced trivial differences in survivals.

The data provided moderate support for differences in survival based on fish origin (table 3). A model based on differences in survival among reaches received 60 percent of the AICc model weight (model 4) and a competing model with the added effect of origin received 26 percent of the model weight (model 5), for a delta AICc value of 1.7. A model based on a common survival for all origins and reaches received 8 percent of the AICc model weight (model 6). Estimates of recapture and survival probabilities were based on model-averaged results of the set of models in table 3 to incorporate model selection uncertainty into the estimates.

The estimates of survival for fish of hatchery and wild origins were almost identical (table 4). Differences in reach-specific survivals between origins were less than 1 percent and the estimated survival through the $276 \mathrm{~km}$ reach from release to Steelhead Lodge was 0.659 (SE 0.049) for hatchery fish and 0.641 (SE 0.051) for wild fish.

Table 3. Summary of models used to estimate apparent survival (Phi) and recapture probabilities $(P)$ of hatchery- and wild-origin juvenile coho salmon in study reaches of the Klamath River during spring 2009 on dates at least four of each group were released.

[Models are based on data from 57 fish released from Iron Gate Hatchery and 57 wild fish taken from a rotary trap on the Scott River. All fish were released in the Klamath River near the hatchery between April 16 and April 30 , 2009. Rankings are based on AICc, a modification of the Akaike's Information Criterion for small samples. A '+' between factors indicates an additive effect, a '*' between factors indicates a multiplicative effect, and a '.' indicates a single value fitted to all levels of origin and reach]

\begin{tabular}{clrrrrrr}
\hline $\begin{array}{c}\text { Model } \\
\text { No. }\end{array}$ & \multicolumn{1}{c}{ Model } & AICc & $\begin{array}{c}\text { Delta } \\
\text { AICc }\end{array}$ & $\begin{array}{c}\text { AICc } \\
\text { weights }\end{array}$ & $\begin{array}{c}\text { Model } \\
\text { likelihood }\end{array}$ & $\begin{array}{c}\text { Number of } \\
\text { parameters }\end{array}$ & Deviance \\
\hline 4 & $\{$ Phi(reach), P(origin+reach)\} & 390.178 & 0.000 & 0.605 & 1.000 & 16 & 22.918 \\
5 & $\{$ Phi(origin+reach), P(origin+reach)\} & 391.899 & 1.721 & 0.256 & 0.423 & 17 & 22.538 \\
6 & $\{$ Phi(.), P(origin+reach) & 394.227 & 4.050 & 0.080 & 0.132 & 10 & 39.448 \\
7 & $\{$ Phi(origin), P(origin+reach)\} & 395.665 & 5.488 & 0.039 & 0.064 & 11 & 38.821 \\
8 & $\{$ Phi(origin*reach), P(origin+reach)\} & 397.067 & 6.890 & 0.019 & 0.032 & 24 & 12.820 \\
9 & $\{$ global model\} & 403.994 & 13.817 & 0.001 & 0.001 & 30 & 6.739 \\
\hline
\end{tabular}


Table 4. Estimated apparent survivals of radio-tagged juvenile coho salmon of hatchery- and wild-origin in study reaches of the Klamath River during spring 2009.

[Results are based on data from 57 hatchery fish from Iron Gate Hatchery and 57 wild fish taken from a rotary trap on the Scott River. All fish were released in the Klamath River near the hatchery between April 16 and April 30, 2009. Results are based on model-averaging the models in table 3. Estimates over multiple reaches were calculated as the product of the individual reach estimates with variances estimated using the delta method]

\begin{tabular}{|c|c|c|c|c|c|c|}
\hline \multirow{2}{*}{$\begin{array}{l}\text { Reach } \\
\text { No. }\end{array}$} & \multirow[b]{2}{*}{ Description } & \multirow{2}{*}{$\begin{array}{c}\text { Reach } \\
\text { length } \\
(\mathrm{km})\end{array}$} & \multirow{2}{*}{$\begin{array}{l}\text { Apparent } \\
\text { survival }\end{array}$} & \multirow{2}{*}{$\begin{array}{l}\text { Standard } \\
\text { error }\end{array}$} & \multicolumn{2}{|c|}{$\begin{array}{c}\text { 95-percent } \\
\text { confidence interval }\end{array}$} \\
\hline & & & & & Lower & Upper \\
\hline & 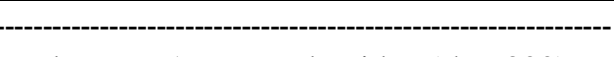 & Hatcher & & & & \\
\hline 1 & Release to Ager Road Bridge (rkm 300) & 9 & 0.919 & 0.029 & 0.840 & 0.960 \\
\hline 2 & Ager Bridge to Shasta River (rkm 288) & 12 & 0.890 & 0.039 & 0.787 & 0.946 \\
\hline 3 & Shasta River to Scott River (rkm 234) & 54 & 0.933 & 0.027 & 0.857 & 0.970 \\
\hline 4 & Scott River to Indian Creek (rkm 178) & 56 & 0.963 & 0.020 & 0.894 & 0.988 \\
\hline 5 & Indian Creek to Salmon River (rkm 107) & 71 & 0.962 & 0.021 & 0.893 & 0.987 \\
\hline 6 & Salmon River to Trinity River (rkm 69) & 38 & 0.961 & 0.021 & 0.889 & 0.987 \\
\hline \multirow[t]{4}{*}{7} & Trinity River to Steelhead Lodge (rkm 33) & 36 & 0.970 & 0.021 & 0.890 & 0.992 \\
\hline & Release to Shasta River & 21 & 0.817 & 0.044 & 0.731 & 0.904 \\
\hline & Release to Scott River & 75 & 0.763 & 0.047 & 0.671 & 0.854 \\
\hline & Release to Steelhead Lodge & 276 & 0.659 & 0.049 & 0.562 & 0.756 \\
\hline 1 & Release to Ager Road Bridge (rkm 300) & $\begin{array}{c}\text { Vild } \\
\end{array}$ & 0.912 & 0.031 & 0.830 & 0.957 \\
\hline 2 & Ager Bridge to Shasta River (rkm 288) & 12 & 0.881 & 0.042 & 0.773 & 0.942 \\
\hline 3 & Shasta River to Scott River (rkm 234) & 54 & 0.931 & 0.028 & 0.851 & 0.970 \\
\hline 4 & Scott River to Indian Creek (rkm 178) & 56 & 0.961 & 0.022 & 0.888 & 0.987 \\
\hline 5 & Indian Creek to Salmon River (rkm 107) & 71 & 0.959 & 0.022 & 0.885 & 0.986 \\
\hline 6 & Salmon River to Trinity River (rkm 69) & 38 & 0.959 & 0.023 & 0.883 & 0.986 \\
\hline \multirow[t]{4}{*}{7} & Trinity River to Steelhead Lodge (rkm 33) & 36 & 0.969 & 0.022 & 0.884 & 0.992 \\
\hline & Release to Shasta River & 21 & 0.804 & 0.047 & 0.713 & 0.896 \\
\hline & Release to Scott River & 75 & 0.749 & 0.049 & 0.653 & 0.845 \\
\hline & Release to Steelhead Lodge & 276 & 0.641 & 0.051 & 0.541 & 0.742 \\
\hline
\end{tabular}

\section{Summary}

This report is a brief summary of the results from the fourth and final year of a study of the survival of juvenile coho salmon in the Klamath River, northern California, downstream of the Iron Gate Dam. Summaries such as this have been provided for each year of the study. The survival probability of hatchery-origin fish from Iron Gate Hatchery (at river kilometer 309) to Steelhead Lodge (at river kilometer 33) in 2009 (0.555, SE 0.038) was slightly greater than in 2008 (0.406, SE 0.032; hatchery tank group) and 2007 (0.497, SE 0.044), but lower than in 2006 (0.653, SE 0.039). The survivals of hatchery-origin and wild fish were similar in 2006 and 2009, the only years for which adequate numbers of wild fish were available for analysis. 


\section{Acknowledgments}

We would like to thank the staff of the California Department of Fish and Game (DFG) at the Iron Gate Hatchery for providing fish and space for this study, as well as the DFG staff operating the Scott River rotary screw trap used to capture the wild fish used in this study. The study would not have been possible without the work of the collaborators: the U.S. Fish and Wildlife Service, Arcata Fishery Resource Office assisted with study design and logistics, tagged fish, and downloaded data; the Karuk and Yurok Tribes downloaded data and performed receiver maintenance; and the USGS Columbia River Research Laboratory assisted with study design, implemented receiver systems, and performed data analysis. The Bureau of Reclamation funded the USGS activities in this study under contract 06AA204092.

\section{References Cited}

Beeman, J.W., 2007, Summary of survival data from juvenile coho salmon in the Klamath River, northern California, 2006: U.S. Geological Survey Open-File Report 2007-1023, 6 p.

Beeman, J.W., 2008, Summary of survival data from juvenile coho salmon in the Klamath River, northern California, 2007: U.S. Geological Survey Open-File Report 2008-1022, 5 p.

Beeman, J.W., Juhnke, S.D., and Hansel, H.C.., 2009, Summary of survival data from juvenile coho salmon in the Klamath River, northern California, 2008: U.S. Geological Survey Open-File Report 2009-1019, 6 p.

Beeman, J.W., Juhnke, S., Stutzer, G., and Hetrick, N., 2008, Survival and migration behavior of juvenile coho salmon in the Klamath River relative to discharge at Iron Gate Dam, 2007: U.S. Geological Survey Open-File Report 2008-1332, 72 p.

Beeman, J.W., Stutzer, G.M., Juhnke, S.D., and Hetrick, N.J., 2007, Survival and migration behavior of juvenile coho salmon in the Klamath River relative to discharge at Iron Gate Dam, 2006: Final report prepared by U.S. Geological Survey and U.S. Fish and Wildlife Service for the Bureau of Reclamation, Mid-Pacific Region, Klamath Basin Area Office, contracts 06AA204092 and 07AA200181, Klamath Falls, Oregon.

Burnham, K.P., and Anderson, D.R., 2002, Model selection and multimodel inference: A practical information-theoretic approach: Springer Verlag, 488 p.

Burnham, K.P., Anderson, D.R., White, G.G., Brownie, C., and Pollock, K.H., 1987, Design and analysis methods for fish survival experiments based on release-recapture: American Fisheries Society Monograph 5, American Fisheries Society, Bethesda, Maryland, 737 p.

Cormack, R.M., 1964, Estimates of survival from the sighting of marked animals: Biometrika v.51, no. 3/4, p. 429-438.

Jolly, G.M., 1965, Explicit estimates from capture-recapture data with both death and immigrationstochastic model: Biometrika, v. 52, no. 1/2, p. 225-247.

Seber, G.A.F., 1965, A note on the multiple-recapture census: Biometrika, v. 52, no. 1/2, p. 249-259.

White, G.C., and Burnham, K.P., 1999, Program MARK: survival estimation from populations of marked animals: Bird Study, v. 46 (supplement), p. 120-138. 
This page left intentionally blank 
Publishing support provided by the U.S. Geological Survey Publishing Network, Tacoma Publishing Service Center

For more information concerning the research in this report, contact the Director, Western Fisheries Research Center

U.S. Geological Survey, 6505 NE 65th Street

Seattle, Washington 98115

http://wfrc.usgs.gov/ 
